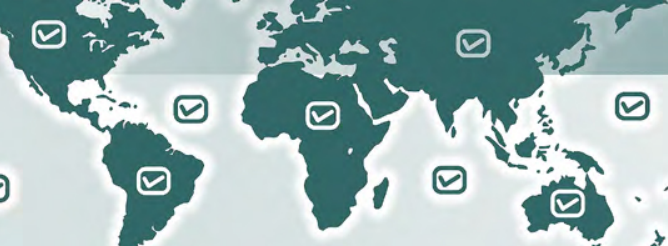

NOTES ON GEOGRAPHIC DISTRIBUTION

\title{
First records of Nausigaster flukei (Diptera: Syrphidae) from Argentina
}

\author{
Ximo Mengual ${ }^{* 1}$ and Guillermo P. López García ${ }^{2}$ \\ 1 Zoologisches Forschungsmuseum Alexander Koenig, Leibniz-Institut für Biodiversität der Tiere. Adenauerallee 160, D-53113 Bonn, Germany \\ 2 Laboratorio de Toxicología Ambiental, Instituto de Medicina y Biología Experimental de Cuyo. CCT-CONICET Mendoza. CC. 131, \\ M 5500 IRA, Mendoza, Argentina \\ * Corresponding author. E-mail: x.mengual@zfmk.de
}

\begin{abstract}
Nausigaster flukei Curran is recorded for the first time from Argentina. New specimens were collected in Mendoza, Jujuy and La Rioja provinces (Argentina), in the Monte and Chaco Phytogeographical Provinces. New records broaden the distribution of this species previously known from Paraguay and south Brazil and represent the first record of the genus Nausigaster from Argentina since 1892.
\end{abstract}

Key words: new records; flower flies; hoverflies; Monte Desert; Chaco

Flower flies (Diptera, Syrphidae) are one of the most diverse families of Diptera, with more than 200 genera and over 6,000 described species worldwide (Brown 2009; Thompson 2013). Adults of this family play a crucial role as pollinators in natural environments and crops, and their larvae are used as biological control agents of pests and are important recyclers of organic matter. For these reasons, flower flies are good bioindicators of the quality of environments and ecosystems (Sommaggio 1999; Burgio and Sommaggio 2007). Nevertheless, the Neotropical syrphid fauna, with 60 genera and about 1,800 described species to date, is still poorly known and more species await description (Thompson et al. 1976, 2010; Thompson 1999). In Argentina, faunistic studies and new records on flower flies are occasional, and some 170 species and 38 genera are reported for this country (Montoya et al. 2012). Lynch Arribálzaga (1891-1892) published the first faunal inventory for Argentina, and Bréthes (1907) presented an overview of the Argentinean dipterans in his catalogue. Since then and besides catalogues, Argentine species of Syrphidae have been treated in short revisions and taxonomic works with a broader scope, e.g., Shannon (1927a, 1927b), Shannon and Aubertin (1933), Blanchard (1938), Lane (1963), Lagrange (1989, 1990, 1993), Kassebeer
(1999) or Wakeham-Dawson et al. (2009) among others. Research on Syrphidae species present in agricultural crops has brought attention more recently (Greco 1995, 1998; Valenciano and Paravano 2002; Bertolaccini et al. 2008; López García and Maza 2013), and works based on collections, such as Bachmann (2012), provide a good starting point to study the Syrphidae fauna in Argentina.

Nausigaster Williston is an endemic New World genus, found from the southern United States to Argentina and is absent from the Chilean subregion (Thompson et al. 2010). Nausigaster species are small flies with tuberculate face, body densely punctate and round abdomen in sectional view with large terga. There are 15 described species of Nausigaster, with nine taxa in the Neotropical Region (Thompson et al. 2010) and only one species cited and described from Argentina, Nausigaster bonariensis Lynch Arribálzaga, 1892 (Lynch Arribálzaga 1892; Curran 1941; Bachmann 2012). Larvae of Nausigaster are saprophagous in wet decaying plant tissues, decaying cacti (Cactaceae) and decaying bromeliads (Bromeliaceae) (Hunter et al. 1912; Carrera et al. 1947; Rotheray et al. 2000), and probably other plants in arid or open habitats.

Nausigaster flukei Curran is a small to mediumsized flower fly with abdominal tergum 2 produced basolaterally into a spur, and a particular wing pattern: extensive dark maculae connected along vein $r_{4+5}$ and cell $R_{1}$ infuscated subapically. It was originally described from Villarica, Paraguay (Curran 1941), and later Carrera et al. (1947) reported it from Pôrto Cabral (São Paulo) and Iguassú (current Laranjeiras do Sul, Paraná), in Brazil (Figure 1). As pointed out by Carrera et al. (1947), some original descriptions do not fit well in the single published key for this genus (Curran 1941), and the intraspecific variability is not well-known since specimens of this genus are present in collections in low number. Hence, Nausigaster is in a serious need of taxonomic revision. 


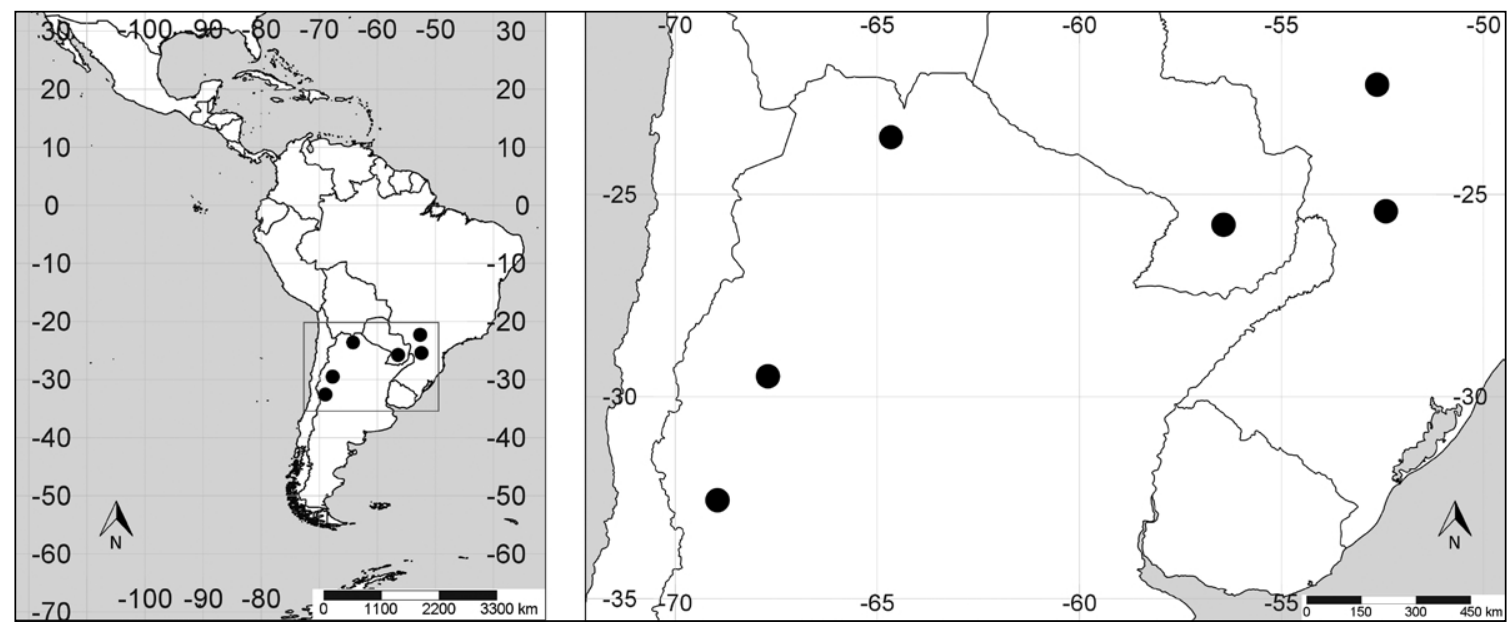

Figure 1. Records of Nausigaster flukei in Brazil, Paraguay and Argentina.

Material examined: ARgentinA: Mendoza, Villavicencio Nature Reserve, 1,183 m, 32 $33^{\prime} 52.0^{\prime \prime}$ S, $068^{\circ} 57^{\prime} 14.2^{\prime \prime}$ W, 8 February - 8 March 2014, Malaise trap. López García, G.P. [1아 IADIZA]; La Rioja, $40 \mathrm{~km}$ SW of Chilecito, Cuesta de la Miranda, 1,610 m, 29 $29^{\prime} 55^{\prime \prime}$ S, $067^{\circ} 42^{\prime} 16^{\prime \prime}$ W, 24 February 1978, hand net. Vecht, J.v.d. [1 $10^{\uparrow}$ ZFMK, ZFMK DIP ooo11897; $10^{\Uparrow}$ RMNH, ZFMK DIP ooo11898];

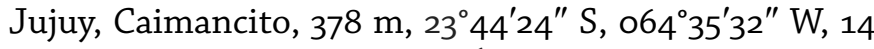
March 1978. Vecht, J.v.d. [1 $10^{\uparrow} 1$ r RMNH, ZFMK DIP ooo11958, 00011959].

Distribution maps were created using SimpleMappr (Shorthouse 2010).

New specimens from Argentina were identified using original descriptions and identification keys for the species of Nausigaster (Curran 1941; Thompson 2006), and morphologically compared with other species material from several collections. New material of $N$. flukei is deposited in the entomological collection of the Argentine Institute for Arid Zones Research (IADIZA), Mendoza (Argentina), in the Naturalis Biodiversity Center (RMNH), Leiden (The Netherlands), and in the Zoologisches Forschungsmuseum Alexander Koenig (ZFMK), Bonn (Germany).

Very little is known about the natural history of Nausigaster and their distribution in Argentina and in the Neotropical Region. The present work reports the first records of $N$. flukei from Argentina, extending the geographical range of the species more than 1,000 $\mathrm{km}$ in a southwest direction (Figure 1). The specimens collected in Mendoza, Jujuy and La Rioja provinces represent the first record of the genus in this country since Lynch Arribálzaga (1892), more than 100 years ago. Moreover, these specimens of $N$. flukei are the first records of these flower flies species associated with arid and semiarid ecosystems in the Central and Northern Monte Phytogeographical Province and in the Chaco Phytogeographical Province (Morrone 2001, 2014). Larvae of Nausigaster may play an important ecological role in these ecosystems as recyclers of organic matter, helping in the decomposition of plant tissues. However, arid and semi-arid habitats are often overlooked in field expeditions or faunistic studies, and they lack a good knowledge on their fauna and ecology. The fact that these records represent the first citation of Nausigaster in those Argentinean provinces and the first record of this genus from Argentina since 1892, points out the necessity to carry out faunistic studies in arid and semi-arid environs in order to understand the crucial role that invertebrates have in the decomposition and pollination processes, especially syrphid flies (MarcosGarcía and Pérez-Bañón 2002; Nderitu et al. 2008; Martínez-Falcón et al. 2012; Andersen and Nelson 2013; Bodlah and Waqar 2013; Traveset et al. 2013, Neil et al. 2014). Furthermore, Monte Phytogeographical Province is threatened by habitat conversion, while Chaco Phytogeographical Province is threatened by overgrazing of domestic livestock, seasonal fires and conversion of natural habitats for agriculture (Dinerstein et al. 1995). These threats urge to study these unique environs in order to have a better knowledge of the habitat dynamics and their fauna.

\section{ACKNOWLEDGEMENTS}

We are very grateful to Ben Brugge (RMNH) for kindly letting us study material in his care. This project was partly funded by the SYNTHESYS grant NL-TAF-2685.

\section{LITERATURE CITED}

Andersen, D.C. and S.M. Nelson. 2013. Floral ecology and insect visitation in riparian Tamarix sp. (saltcedar). Journal of Arid Environments 94: 105-112. doi: 10.1016/j.jaridenv.2013.03.009

Bachmann, A.O. 2012. A catalog of the types of Stratiomyidae, Tabanidae, Asilidae sensu lato, and Syrphidae (Insecta, Diptera) deposited in the Museo Argentino de Ciencias Naturales, Buenos Aires (MACN): with an appendix on types of Tabanidae deposited in the Instituto "Dr. Carlos G. Malbrán", Buenos Aires (ANLIS). Revista del Museo Argentino de Ciencias Naturales 14(1): 97-123. http://www.macn.secyt.gov.ar/investigacion/descargas/ publicaciones/revista/14/rns_vol14-1_097-123.pdf

Bertolaccini, I., P. Andrada and O. Quaino. 2008. Efecto de franjas 
marginales en la atracción de Coccinellidae y Syrphidae, depredadores de áfidos en trigo, en la zona central de la provincia de Santa Fe, Argentina. Agronomía Tropical 58(3): 267-276. http://sian.inia.gob.ve/repositorio/revistas_ci/Agronomia\%20 Tropical/at5803/pdf/bertolaccini_i.pdf

Blanchard, E.E. 1938: Descripciones y anotaciones de dípteros argentinos. Anales de la Sociedad Científica Argentina 126: 345-386.

Bodlah, I. and M. Waqar. 2013. Pollinators visiting summer vegetables ridge gourd (Luffa acutangula), bitter gourd (Momordica charantia L.) and brinjal (Solanum melongena). Asian Journal of Agriculture and Biology 1(1): 8-12. http://www.asianjab.com/wp-content/ uploads/2013/04/MS-No.-02-Pollinators-Luffa-acutangulaMomordica-charantia-L-Solanum-melongena.pdf

Brèthes, J. 1907. Catálogo de los dípteros de las Repúblicas del Plata. Anales del Museo Nacional de Buenos Aires 16 $\left(3^{\text {a }}\right.$ Serie, 9): 277-305. https://archive.org/details/cbarchive_40356_catlogo delosdpterosdelasrepblig999

Brown, B.V. 2009. Introduction; pp. 1-7, in: B.V. Brown, A. Borkent, J.M. Cumming, D.M. Wood, N.E. Woodley and M.A. Zumbado (eds.). Manual of Central American Diptera. Volume 1. Ottawa: NRC Research Press.

Burgio, G. and D. Sommaggio. 2007. Syrphids as landscape bioindicators in Italian agroecosystems. Agriculture, Ecosystems \& Environment 120: 416-422. doi: 10.1016/j.agee.2006.10.021

Carrera, M., H. de Souza Lopes and J. Lane. 1947. Contribuição ao conhecimento dos "Microdontinae" neotrópicos e descrição de duas novas espécies de "Nausigaster" Williston (Diptera, Syrphidae). Revista Brasileira de Biologia 7: 471-486.

Curran, C.H. 1941. New American Syrphidae. Bulletin of the American Museum of Natural History 78: 243-304. http:// digitallibrary.amnh.org/dspace/handle/2246/377

Dinerstein, E., D.M. Olson, D.J. Graham, A.L. Webster, S.A. Primm, M.P. Bookbinder and G. Ledec. 1995. Una evaluación del estado de conservación de las ecorregiones terrestres de América Latina y el Caribe. World Bank, Washington, D.C. 135 pp.

Greco, C.F. 1995. Fenología y selección de hábitat de las especies de sírfidos afidófagos (Dipt.: Syrphidae) más frecuentes en cultivos cerealeros y forrajeros en la provincia de Buenos Aires, Argentina. Entomophaga 40(3-4): 317-320.

Greco, C.F. 1998. Sirfidos afidófagos (Diptera, Syrphidae): identificación rápida a campo de estados preimaginales y lista de enemigos naturales de las especies más frecuentes en cereales y forrajes en la provincia de Buenos Aires (Argentina). Acta entomologica chilena 22: 7-11.

Hunter, W.D., F.C. Pratt and J.D. Mitchell. 1912. The principal cactus insects of the United States. USDA, Bureau of Entomology, Bulletin 113: 1-71.

Kassebeer, C.F.1999. Die neotropischen Arten der Gattung Scaeva Fabricius, 1805 (Diptera, Syrphidae. Dipteron 2: 93-108.

Lagrange, E.B. 1989. Revisión de las especies argentinas del grupo scutellaris del género Palpada Macquart, 1834 (Diptera, Syrphidae). Neotrópica (La Plata) 35: 118-120.

Lagrange, E.B. 1990. Las especies argentinas del género Meromacrus Rondani (Diptera, Syrphidae). Revista Brasileira de Entomología 34: 489-498.

Lagrange, E.B. 1993. Dos especies nuevas del género Dolichogyna (Diptera: Syrphidae). Neotropica (La Plata) 38: 119-126.

Lane, J. 1963. Insecta Patagonia (Diptera: Syrphidae). Revista de la Sociedad Entomológica Argentina 25: 17-19.

López García, G. and N. Maza. 2013. Lista de sírfidos afidófagos y primeros registros de Pseudodoros clavatus y Eupeodes rojasi (Diptera: Syrphidae), potenciales agentes de control biológico en la provincia de Mendoza, Argentina. Revista de la Sociedad Entomológica Argentina 72(3-4): 237-240. http://www.biotaxa. org/RSEA/article/view/4208/6236
Lynch Arribálzaga, F. 1891-1892. Dipterología Argentina, Syrphidae. Anales de la Sociedad Científica Argentina 32: 80-99, 118-131, 194-202, 247-256, 307-314; 33: 51-58, 111-121, 189-199, 236-253; 34: 33-46, 173-192, 242-28o.

Marcos-García, M.A. and C. Pérez-Bañón. 2002. Life cycle, adult and immature stages of a new species of Copestylum (Diptera: Syrphidae) from Mexico reared from Cactaceae. Annals of the Entomological Society of America 95: 432-440. http://biostor. org/reference/23012

Martínez-Falcón, A.P., M. A. Marcos-García, C.E. Moreno, and G.E. Rotheray. 2012. A critical role for Copestylum larvae (Diptera, Syrphidae) in the decomposition of cactus forests. Journal of Arid Environments 78: 41-48. doi:10.1016/j.jaridenv.2011.10.010

Montoya, A.L., S.P. Perez, and M. Wolff. 2012. The diversity of flower flies (Diptera: Syrphidae) in Colombia and their Neotropical distribution. Neotropical Entomology 41:46-56. doi: 10.1007/ s13744-012-0018-z

Morrone, J.J. 2001. Biogeografía de América Latina y el Caribe. Manuales y Tesis SEA, Volumen 3. Zaragoza. 148 pp. http:// www.sea-entomologia.org/Publicaciones/ManualesTesis/ ManualesTesis3/manualestesis3.htm

Morrone, J.J. 2014. Biogeographical regionalisation of the Neotropical region. Zootaxa 3782: 1-110. doi: 10.11646/zootaxa.3782.1.1

Nderitu, J., G. Nyamasyo, M. Kasina and M.L. Oronje. 2008. Diversity of sunflower pollinators and their effect on seed yield in Makueni District, Eastern Kenya. Spanish Journal of Agricultural Research 6(2): 271-278. doi: 10.5424/sjar/2008062-318

Neil, K., J. Wu, C. Bang and S. Faeth. 2014. Urbanization affects plant flowering phenology and pollinator community: effects of water availability and land cover. Ecological Process 3: 17. doi: 10.1186/ s13717-014-0017-6

Rotheray, G.E., M.A. Marcos-García, E.G. Hancock and F.S. Gilbert. 2000. The systematic position of Alipumilio and Nausigaster based on early stages (Diptera, Syrphidae). Studia Dipterologica 7: 133-144.

Shannon, R.C. 1927a. Some new Diptera from Argentina. Revista de la Sociedad Entomológica Argentina 1(4): 31-42.

Shannon, R.C. 1927b. A review of the South American two-winged flies of the family Syrphidae. Proceedings of the United States National Museum 70(9) [= No. 2658]: 1-34. doi: 10.5479/ si.00963801.70-2658.1

Shannon, R.C. and D. Aubertin. 1933. Syrphidae. Diptera of Patagonia and South Chile. British Museum (Natural History). Part VI. 3: 120-170.

Shorthouse, D.P. 2010. SimpleMappr, an online tool to produce publication-quality point maps. http://www.simplemappr.net

Sommaggio, D. 1999. Syrphidae: can they be used as environmental bioindicators? Agriculture Ecosystems and Environment 74: 343-356. doi: 10.1016/So167-8809(99)00042-o

Thompson, F.C. 1999. A key to the genera of the flower flies (Diptera: Syrphidae) of the Neotropical Region including descriptions of new genera and new species and a glossary of taxonomic terms. Contributions on Entomology International 3: 322-378. https:// repository.si.edu/handle/10088/17492

Thompson, F.C. 2006. Primer taller de identificación de Syrphidae del Neotrópico, 21 a 27 de febrero de 2006, Cali, Colombia. Universidad del Valle, Facultad de Ciencias, 86o pp.

Thompson, F.C. 2013. Family Syrphidae. In: F.C. Thompson and T. Pape (eds.). Systema Dipterorum. Version 1.5. http://www. diptera.org

Thompson, F.C., G.E. Rotheray, and M.A. Zumbado. 2010. Family Syrphidae; pp. 763-792, in: B.V. Brown, A. Borkent, J.M. Cumming, D.M. Wood, N.E. Woodley, and M.A. Zumbado (eds.). Manual of Central American Diptera. Volume 2. Ottawa: NRC Research Press.

Thompson, F.C., J.R. Vockeroth, and Y.S. Sedman. 1976. Family 
Syrphidae. Catalogue of the Diptera of America south of the United States. Museu de Zoologia, Universidade de São Paulo, Brasil. 46: 195 pp. https://repository.si.edu/handle/10088/17070

Traveset, A., R. Heleno, S. Chamorro, P. Vargas, C.K. McMullen, R. Castro-Urgal, M. Nogales, H.W. Herrera, and J.M. Olesen. 2013. Invaders of pollination networks in the Galápagos Islands: emergence of novel communities. Proceedings of the Royal Society B: Biological Sciences 280: 20123040. doi: 10.1098/ rspb.2012.3040

Valenciano, J.B., and A.S. Paravano. 2002. Población de sírfidos (Diptera: Syrphidae) depredadores de pulgones y presencia de áfidos parasitados sobre alfalfa en la provincial de Santa Fe,
Argentina. Revista FAVE - Ciencias Agrarias 1(2): 47-55.

Wakeham-Dawson, A., A.G. Jones, and F.C. Thompson. 2009

Falkland Islands Syrphidae (Diptera). Dipterists Digest 16: 65-71. https://repository.si.edu/handle/10088/14865

Author contributions: GPLG collected and studied recent specimens, XM studied material and confirmed identifications, and GPLG and XM wrote the text.

Received: 22 June 2015

Accepted: 21 September 2015

Academic editor: Jonas Döge 